\title{
Polynucleotide:adenosine glycosidase activity of saporin-L1: effect on DNA, RNA and poly(A)
}

\author{
Luigi BARBIERI ${ }^{\star}$, Paola VALBONESI, Paola GORINI, Annalisa PESSION and Fiorenzo STIRPE \\ Dipartimento di Patologia sperimentale dell'Università degli Studi di Bologna, Via San Giacomo 14, I-40126 Bologna, Italy
}

The ribosome-inactivating proteins (RIPs) are a family of plant enzymes for which a unique activity has been determined: rRNA $\mathrm{N}$-glycosidase, which removes adenine at a specific universally conserved position ( $\mathrm{A}^{4324}$ in the case of rat ribosomes). Here we report that saporin-L1, a RIP from the leaves of Saponaria officinalis, recognizes other substrates, including RNAs from different sources, DNA and poly(A). Saporin-L1 depurinated DNA extensively and released adenine from all adenine-containing polynucleotides tested. Adenine was the only base released from DNA or artificial polynucleotides. The characteristics of the reactions catalysed by saporin-L1 have been determined: optimal $\mathrm{pH}$ and temperature, ionic requirements, and the kinetic parameters $K_{\mathrm{m}}$ and $k_{\text {cat }}$. The reaction proceeded without cofactors, at low ionic strength, in the absence of $\mathrm{Mg}^{2+}$ and $\mathrm{K}^{+}$. Saporin-L1 had no activity towards various adenine-containing non-polynucleotide compounds (cytokinins, cofactors, nucleotides). This plant protein may now be classified as a polynucleotide:adenosine glycosidase.

\section{INTRODUCTION}

Plant ribosome-inactivating proteins (RIPs), consisting either of a single chain (type 1) or of two chains, one of which has lectinlike properties (type 2), are enzymes that irreversibly damage ribosomes, leading to the inhibition of protein synthesis (reviewed in [1]). The role of RIPs in plant physiology is not clear. Based on their variable activity towards heterologous and autologous plant ribosomes, several roles have been proposed: anti-viral activity, anti-fungal activity, defence against predators, a role in the programmed arrest of metabolism during senescence, and also a role as storage proteins. The cytotoxicity induced by the ribosome-inactivating activity of RIPs suggested their use in the therapy of a variety of human diseases. Their use has been envisaged either as such (e.g. as anti-HIV agents), or after linkage to antibodies (immunotoxins) or other carriers, which can provide RIPs with specific cytotoxic effects [1]. Several therapeutic strategies involving the use of RIPs are currently under evaluation. Studies on the molecular target of RIPs may thus help us to understand the pharmacology of these proteins.

The molecular mechanism by which RIPs act on ribosomes was elucidated by Endo and Tsurugi [2], who found that ricin, the best known type 2 RIP, is an N-glycosidase that releases a single adenine from rRNA within a universally conserved GAGA sequence $\left(\mathrm{A}^{4324}\right.$ in the case of rat liver $28 \mathrm{~S}$ rRNA; $\mathrm{A}^{2660}$ in Escherichia coli $23 \mathrm{~S}$ rRNA) [2]. The intact structure of ribosomes is essential for RIP activity; ricin acts on naked rRNA from rat liver or E. coli at very much lower rates $\left(10^{5}\right.$-fold $)$ than on intact mammalian ribosomes. All RIPs of either type tested so far have been found to possess $\mathrm{N}$-glycosidase activity towards eukaryotic and bacterial rRNA, with the same specificity restricted to a single adenine residue (reviewed in [1]). It was thus assumed that all RIPs share the same mechanism of action. However, differences in toxicity towards various cell lines, in effects on ribosomes from plants or bacteria [1,3], in the requirement for cofactors [4], and in the minimal structure of the adenine-containing loop substrate [5] pointed to a substantial diversity among RIPs. A difference in substrate specificity among RIPs was shown by the observation that some saporins (RIPs from Saponaria officinalis) and, to a lesser extent, other type 1 RIPs release more than one adenine per mol of ribosomes, clearly depurinating rRNA at multiple sites [6,7].

All of the biological properties of RIPs were attributed to the inactivation of ribosomes. However, some observations could not be equated with this view: (i) an effect of RIPs on viral DNA synthesis independent of the action of ribosomes was postulated by Teltow et al. [8], who observed that pokeweed anti-viral protein (PAP) inhibits viral DNA synthesis to a much greater extent than cell protein synthesis in cells infected with the herpes simplex virus; (ii) histological aspects of lesions induced by RIPs [9] are quite different from those obtained with other known protein synthesis inhibitors, and (iii) some aspects of the antiviral activity of RIPs could not be attributed to this property [10-12]. Furthermore, preliminary results showed that some saporins released adenine from all RNAs tested, and also from poly(A) and DNA, but did not affect ribomononucleotides, thus being actually polynucleotide:adenosine glycosidases [13]. Finally, two isoforms of PAP, PAP from seeds (PAP-S) and an RIP from Hura crepitans, release adenine from DNA [14].

In the present study, we have defined the optimal assay conditions, its action with various substrates and the main kinetic constants for saporin-L1.

\section{EXPERIMENTAL}

\section{Materials}

Saporins were purified as described in [7]. This purification protocol includes two ion-exchange and two hydrophobicinteraction chromatographic steps, and yields $>99 \%$ pure protein as judged by electrophoresis and analytical FPLC [7]. Phosphocreatine, creatine kinase, GTP, poly(A), poly(C),

Abbreviations used: RIP, ribosome-inactivating protein; hsDNA, DNA from herring sperm, hdpDNA, human deproteinized DNA; PAP(-S), pokeweed anti-viral protein (from seeds).

* To whom correspondence should be addressed. 
poly $(\mathrm{G})$, poly $(\mathrm{U})$, genomic RNA from tobacco mosaic virus $\left(M_{\mathrm{r}}\right.$ $\left.2.1 \times 10^{6}\right)$, rRNA from $E$. coli $\left(16 \mathrm{~S}\right.$ plus $\left.23 \mathrm{~S} ; M_{\mathrm{r}} 1.75 \times 10^{6}\right)$ and bacteriophage MS 2 RNA $\left(M_{\mathrm{r}} 1.18 \times 10^{6}\right)$ were from Boehringer G.m.b.H., Mannheim, Germany. Phenylalanine-specific tRNA from Saccharomyces cerevisiae $\left(M_{\mathrm{r}} 25 \times 10^{3}\right)$ was from Sigma, St. Louis, MO, U.S.A. Globin mRNA $\left(\alpha\right.$ - plus $\beta$-globin; $M_{\mathrm{r}}$ $1.54 \times 10^{6}$ ) was prepared from a rabbit reticulocyte lysate [15] as described by Aviv and Leder [16]. Poly(A)- RNA from Bryonia dioica leaves was prepared essentially as described in [17]. Genomic RNA (single-stranded mRNA positive plus one small satellite; $M_{\mathrm{r}} 1.49 \times 10^{6}$ ) from artichoke mottled crinkle virus, a gift from Dr. E. Benvenuto, University of Rome, Italy, was prepared by phenol extraction and ethanol precipitation from purified virus isolates. DNA from herring sperm (hsDNA; Sigma) was mechanically sheared and made RNA-free by treatment with DNase-free RNase A (Boehringer) for $2.5 \mathrm{~h}$ at $37^{\circ} \mathrm{C}$. DNA was then repeatedly precipitated in ethanol to remove the enzyme and, when indicated, was melted by heating at $90{ }^{\circ} \mathrm{C}$ for $5 \mathrm{~min}$, followed by rapid cooling on ice. High- $M_{\mathrm{r}}$ human deproteinized DNA (hdpDNA) was prepared from human lymphocytes, and separated by density centrifugation through Ficoll-Hypaque [18] followed by SDS/proteinase K lysis [19].

Nucleic acids were extracted with phenol/chloroform, precipitated with ethanol, resuspended in $10 \mathrm{mM}$ Tris/ $\mathrm{HCl}$ buffer, $\mathrm{pH} 7.4$, containing $1 \mathrm{mM} \mathrm{MgCl}$ and incubated at $37^{\circ} \mathrm{C}$ for $2 \mathrm{~h}$ with RNase A $(1 \mathrm{mg} / \mathrm{ml})$. Following a phenol/chloroform extraction, sodium acetate was added to a final concentration of $0.2 \mathrm{M}$ and DNA was precipitated with ethanol and dissolved in $10 \mathrm{mM}$ Tris/ $\mathrm{HCl}$ buffer, $\mathrm{pH} 7.4$, containing $1 \mathrm{mM}$ EDTA; the $A_{260} / A_{280}$ ratio of the DNA was 1.7 . Adenine, adenosine, adenine mononucleotides, cytosine, guanine, thymine, uracil and cytokinins were from Sigma. L-[U- $\left.{ }^{14} \mathrm{C}\right]$ Phenylalanine (sp. radioactivity $19 \mathrm{GBq} / \mathrm{mmol}$ ) was from Amersham. Material and equipment for low-pressure chromatography were from Pharmacia LKB (Uppsala, Sweden). All other reagents were of analytical or molecular biology grade and, when possible, RNasefree. Water was Milli-Q (Waters-Millipore). Chloroacetaldehyde was prepared according to [20]. Ready Safe was purchased from Beckman.

\section{Determination of polynucleotide:adenosine glycosidase activity}

Unless otherwise stated, polynucleotide:adenosine glycosidase activity was determined by measuring adenine released from the substrate after derivatization to its fluorescent derivative ethenoadenine after separation by HPLC (see below). In a typical experiment 18 samples were run, including the substrate alone and five standard adenine samples. The reaction was stopped by placing in liquid nitrogen, polynucleotides were removed by double precipitation in ethanol, and adenine contained in the supernatant was measured.

Reaction conditions are reported in the legends to the pertinent Tables and Figures, except for the following experiments. Reaction conditions for competition assays were $20 \mathrm{mM}$ sodium citrate/phosphate, $\mathrm{pH} 6.0,100 \mathrm{mM} \mathrm{NH}_{4} \mathrm{Cl}, 10 \mathrm{mM}$ magnesium acetate and $0.2 \mathrm{pmol}$ of saporin-L1 in a final volume of $50 \mu \mathrm{l}$ for $20 \mathrm{~min}$ at $30^{\circ} \mathrm{C}$. Analogues of the substrate were at a concentration 10 -fold greater $(6000 \mathrm{pmol})$ than that of the substrate poly(A) (600 pmol as adenosine residues). Adenine released was determined by HPLC.

The release of free bases other than adenine from hsDNA was measured under the following reaction conditions: $20 \mathrm{mM}$ sodium acetate buffer, $\mathrm{pH} 4.0,100 \mathrm{mM} \mathrm{NH}_{4} \mathrm{Cl}$, at $30{ }^{\circ} \mathrm{C}, 40 \mu \mathrm{g}$ of hsDNA and 10 pmol of saporin-L1, in a final volume of $50 \mu 1$.
The reaction was stopped by placing in liquid nitrogen, DNA was removed by double precipitation in ethanol, and free bases released were measured by HPLC. Several controls were run: (i) DNA alone; (ii) DNA with free bases added (5000 pmol), incubated for $40 \mathrm{~min}$; (iii) DNA plus saporin-L1, without incubation; and (iv) DNA with saporin-L1 and free bases added, incubated for $40 \mathrm{~min}$. The sensitivity of the test could demonstrate the presence of free bases at a concentration more than 100-fold lower than that of the adenine actually released in the experiment.

The reaction conditions for measuring the release of free bases other than adenine from artificial homoribopolynucleotides were $20 \mathrm{mM}$ Tris/ $\mathrm{HCl}, \mathrm{pH} 7.8,100 \mathrm{mM} \mathrm{NH}_{4} \mathrm{Cl}, 10 \mathrm{mM}$ magnesium acetate, $100 \mathrm{mg}$ of polynucleotide and, when appropriate, $30 \mathrm{pmol}$ of saporin-L1 and $20 \mathrm{nmol}$ of free bases as an internal standard, in a final volume of $50 \mu \mathrm{l}$, for $40 \mathrm{~min}$ at $25^{\circ} \mathrm{C}$. The reaction was stopped by placing in ice, and polynucleotides were removed by precipitation in ethanol and centrifugation. Bases released into the supernatant were measured spectrophotometrically at $260 \mathrm{~nm}$. The sensitivity of the test could demonstrate the presence of free bases at a concentration 30-fold lower than that of the adenine released from poly(A), run as a positive control under the same experimental conditions.

Reaction conditions for the exhaustive deadenylation of poly(A) by saporin-L1 were $20 \mathrm{mM}$ sodium acetate buffer, $\mathrm{pH} 6.0,100 \mathrm{mM} \mathrm{NH}_{4} \mathrm{Cl}, 10 \mathrm{mM}$ magnesium acetate, at $30^{\circ} \mathrm{C}$, poly(A) (equivalent to $100 \mathrm{pmol}$ of adenosine residues) and $10 \mathrm{pmol}$ of saporin-L1, in a final volume of $50 \mu \mathrm{l}$. The reaction was run for up to $2 \mathrm{~h}$. Adenine released was measured by HPLC.

Kinetic analyses were performed using the Enzfitter program.

\section{Determination of adenine and other bases}

Adenine was measured by fluorescence analysis [21], essentially following the procedure described in [22] after derivatization to ethenoadenine using chloroacetaldehyde. A derivatization rate of approx. $50 \%$ was achieved. Portions diluted appropriately in Milli-Q water were analysed with a Kontron high-pressure liquid chromatograph equipped with a model SFM 25 spectrophotofluorimeter and a model 450 MT data system for chromatography control and data analysis. The column, a reverse-phase Spherisorb C18 $(5 \mu \mathrm{m}$ particle size; $25 \mathrm{~cm} \times 0.46 \mathrm{~cm})$, was equilibrated in $20 \mathrm{mM}$ sodium tetraborate/phosphoric acid buffer, $\mathrm{pH} 7.7$, containing $16 \%(\mathrm{v} / \mathrm{v})$ methanol, and eluted with a linear gradient $(10 \mathrm{ml})$ of $16-32 \%$ methanol in the same buffer. The flow rate was $1 \mathrm{ml} / \mathrm{min}$. The spectrophotofluorimeter was set at $315 \mathrm{~nm}$ excitation and $415 \mathrm{~nm}$ emission. Adenine was determined by plotting area values on to the standard curve obtained in each experiment.

For analysis of bases other than adenine, portions $(6 \%)$ of the samples were applied to a minibore Spherisorb C18 reversephase column ( $5 \mu \mathrm{m}$ particle size; $25 \mathrm{~cm} \times 0.2 \mathrm{~cm}$ ), equilibrated in $20 \mathrm{mM}$ sodium tetraborate/phosphoric acid buffer, $\mathrm{pH}$ 7.7. Elution was with a $7.5 \mathrm{ml}$ gradient of $0-40 \%$ methanol in the same buffer at $0.25 \mathrm{ml} / \mathrm{min}$. Bases were measured spectrophotometrically with an on-line Kontron 432 detector by absorbance at $260 \mathrm{~nm}$.

\section{Preparation of purified rat liver ribosomes}

Rat liver ribosomes were prepared essentially as described elsewhere [23] in RNase-free conditions. Their concentration was determined by the $A_{260}$ as described in [24], assuming that 12.5 absorbance units $/ \mathrm{ml}$ was equivalent to $1 \mathrm{mg} / \mathrm{ml}$ and that $1 \mathrm{mg}$ contained 250 pmol of ribosomes. Ribosomes were stored in aliquots at $-80{ }^{\circ} \mathrm{C}$. 


\section{Poly(U)-directed phenylalanine polymerization}

Poly(U)-directed phenylalanine polymerization by rat liver ribosomes was performed in conditions optimized for polymerization at $37^{\circ} \mathrm{C}$, for $10 \mathrm{~min}$, in $100 \mu \mathrm{l}$ containing $2 \mathrm{pmol}$ of ribosomes, $20 \mathrm{mM}$ Tris $/ \mathrm{HCl}$ buffer, $\mathrm{pH} 7.8,100 \mathrm{mM} \mathrm{NH}_{4} \mathrm{Cl}, 7 \mathrm{mM}$ magneium acetate, $1 \mathrm{mM}$ dithiothreitol, $2 \mathrm{mM}$ ATP, $0.6 \mathrm{mM}$ GTP, $10 \mathrm{mM}$ phosphocreatine, $30 \mu \mathrm{g}$ of creatine kinase, $600 \mathrm{kBq}$ of L$\left[\mathrm{U}-{ }^{14} \mathrm{C}\right]$ phenylalanine, $80 \mu \mathrm{g}$ of poly(U), and rat liver $\mathrm{S}-70$ supernatant (100 $\mu \mathrm{g}$ of protein) [25]. The reactions were stopped on ice by the addition of $0.5 \mathrm{ml}$ of $0.1 \mathrm{M} \mathrm{KOH}$. Protein was precipitated with $0.5 \mathrm{ml}$ of $20 \%$ (w/v) trichloroacetic acid. Precipitated material was collected on fibreglass filters (Whatman GF/A) and washed four times with $5 \%(\mathrm{w} / \mathrm{v})$ trichloroacetic acid, and the radioactivity was measured in a liquid scintillation counter after the addition of $5 \mathrm{ml}$ of Ready Safe scintillation cocktail.

\section{RESULTS}

\section{Effect of saporin-L1 on various adenine-containing substrates}

Saporin-L1 released adenine from RNA from various animal, plant, bacterial and viral sources, from hsDNA and human lymphocyte DNA, and from poly(A) (Table 1), but not from several other adenine- and adenosine-containing compounds, including nucleosides and nucleotides (ATP, dATP, adenosine, 5'-ADP, 5'-AMP, 3'-AMP and 3'-,5'-ADP), cofactors (NAD ${ }^{+}$, $\mathrm{NADP}^{+}, \mathrm{FAD}, \mathrm{CoA}$, vitamin $\mathrm{B} 12$ and $S$-adenosylmethionine), plant cytokinins [6- $(\gamma, \gamma$-dimethylallylamino)purine, $6-(\gamma, \gamma$-dimethylallylamino)purine riboside, 6-benzylaminopurine, 6benzylaminopurine riboside, kinetin (6-furfurylaminopurine),

\section{Table 1 Activity of saporin-L1 with various adenine-containing substrates}

Unless otherwise stated, reaction conditions were those that are optimal for poly $(A)$, as described in the legend to Figure 1(d). Adenine release was measured by HPLC. Other experimental conditions are described in the Experimental section. In the case of complex substrates such as $23 \mathrm{~S}+16 \mathrm{~S}$ rRNA, 1 pmol of substrate polynucleotide is considered as representing $1 \mathrm{pmol}$ of each single species present. Controls run without enzyme released $\leqslant 0.2 \mathrm{pmol}$ of adenine/min and were not considered for calculations. A control with enzyme alone contained no free adenine. n.a., not applicable, since the macromolecular structure is not homogeneous. TMV, tobacco mosaic virus; AMCV, artichoke mottled crinkle virus.

\begin{tabular}{|c|c|c|}
\hline \multirow[b]{2}{*}{ Substrate } & \multicolumn{2}{|l|}{ Adenine released } \\
\hline & $\begin{array}{l}\text { (pmol/min per } \\
\text { pmol of enzyme) }\end{array}$ & $\begin{array}{l}\text { (pmol/pmol of } \\
\text { polynucleotide) }\end{array}$ \\
\hline Poly(A) & 299 & n.a. \\
\hline hsDNA & 101 & n.a. \\
\hline $\begin{array}{l}\text { tRNA } \\
\text { cerevisiae }\end{array}$ & 48 & 1.4 \\
\hline $\begin{array}{l}\text { Globin }(\alpha+\beta) \text { mRNA from rabbit } \\
\text { reticulocyte }\end{array}$ & 41 & 75 \\
\hline Genomic RNA from bacteriophage MS 2 & 33 & 158 \\
\hline rRNA (16 S + 23 S) from E. coli & 33 & 68 \\
\hline Poly(A) ${ }^{-}$RNA from Bryonia dioica & 28 & n.a. \\
\hline Genomic RNA from TMV & 20 & 52 \\
\hline Genomic RNA from AMCV* & 16 & 95 \\
\hline hdpDNA† & 4 & n.a. \\
\hline \multicolumn{3}{|c|}{$\begin{array}{l}\text { * Different experimental conditions were used: } 3 \mathrm{pmol} \text { of enzyme, } 20 \mathrm{mM} \text { Tris/HCl buffer, } \\
\text { TH } 7.8,100 \mathrm{mM} \mathrm{NH} \mathrm{Cl}_{4}, 10 \mathrm{mM} \text { magnesium acetate, at } 25^{\circ} \mathrm{C} \text { for } 40 \mathrm{~min} \text {. } \\
\text { † Different experimental conditions were used: } 0.17 \mathrm{pmol} \text { of enzyme, } 1 \mu \mathrm{g} \text { of hdpDNA in } \\
50 \mathrm{mM} \text { sodium acetate buffer, } \mathrm{pH} 4.0,160 \mathrm{mM} \mathrm{KCl}, 1.25 \mathrm{mM} \text { magnesium acetate, at } 37^{\circ} \mathrm{C} \\
\text { or } 40 \text { min. }\end{array}$} \\
\hline
\end{tabular}

Table 2 Effect of homoribopolynucleotides other than poly(A) on polynucleotide deadenylation by saporin-L1

Reaction conditions were those optimal for poly(A), as described in the legend to Figure 1(d), except for substrate (as indicated) and enzyme added ( $0.1 \mathrm{pmol} / \mathrm{sample})$. The substrate was $600 \mathrm{pmol}$ of poly $(\mathrm{A})$ or $1.5 \mu \mathrm{g}$ of $23 \mathrm{~S}+16 \mathrm{~S}$ rRNA. For substrates and competitors, pmol refers to nucleoside residues. Adenine released was measured by HPLC. Other experimenta conditions are described in the Experimental section.

\begin{tabular}{|c|c|c|c|}
\hline \multicolumn{2}{|l|}{ Additions } & \multicolumn{2}{|l|}{ Adenine released } \\
\hline Substrate & Competitor & $\begin{array}{l}\text { (pmol/min per } \\
\text { pmol of enzyme) }\end{array}$ & ( $\%$ of control) \\
\hline Poly(A) & None (control without enzyme) & $<0.1$ & \\
\hline Poly(A) & None (control with enzyme) & 35.7 & $(100)$ \\
\hline Poly(A) & Poly(U) (6000 pmol) & 8.8 & 24.7 \\
\hline Poly (A) & Poly(C) (6000 pmol) & 34.3 & 96.1 \\
\hline Poly (A) & Poly(G) (6000 pmol) & 30.3 & 85.0 \\
\hline $23 \mathrm{~S}+16 \mathrm{~S}$ rRNA & None (control without enzyme) & $<0.1$ & \\
\hline $23 S+16 S$ rRNA & None (control with enzyme) & 46.6 & $(100)$ \\
\hline $23 \mathrm{~S}+16 \mathrm{~S}$ rRNA & Poly(U) $(15 \mu \mathrm{g})$ & 38.6 & 82.8 \\
\hline
\end{tabular}

kinetin riboside, zeatin and zeatin riboside] (results not shown). Some of these compounds [kinetin and its riboside, 6-benzylaminopurine and its riboside, 6- $(\gamma, \gamma$-dimethylallylamino)purine, zeatin, 5'-AMP, 3'-AMP, 3',5'-ADP] added at a 10-fold molar excess (as adenine residues) with respect to poly(A) did not significantly affect the depurination of poly(A) (results not shown). Release of adenine from poly(dA) could not be measured because this fragile substrate was degraded during the procedure used for the determination of the released adenine.

Saporin-L1 did not release free bases other than adenine from hsDNA using the experimental conditions reported in the Experimental section, and did not act on $\operatorname{poly}(\mathrm{C})$, $\operatorname{poly}(\mathrm{G})$ or $\operatorname{poly}(\mathrm{U})$ (results not shown).

A competition study on the depurination of poly(A) was performed with $\operatorname{poly}(\mathrm{U}), \operatorname{poly}(\mathrm{C})$ and $\operatorname{poly}(\mathrm{G})$ to assess the possibility of saporin-L1 binding to non-adenine-containing polynucleotides. Only an excess of poly(U), which itself binds tightly to poly(A), inhibited the reaction with poly(A), but it did not affect the rection with $E$. coli rRNA, to which it does not bind (Table 2).

\section{Optimization of reaction conditions}

Optimal conditions for saporin-L1 activity were determined with three substrates, i.e. MS 2 RNA, poly(A) and hdpDNA, except for ionic requirements which were determined with poly(A) and hdpDNA only. Kinetic constants were determined with poly(A). Starting conditions for MS 2 RNA and poly(A) for determination of the effects of $\mathrm{pH}$, temperature and enzyme concentration were those determined as optimal for cell-free translation systems, often used to determine RIP activity. Starting conditions for hdp DNA were different, since the availability of this substrate was lower and the optimal $\mathrm{pH}$ was already known from preliminary experiments.

The optimal conditions with the three substrates appeared to differ substantially. (i) The effect of $\mathrm{pH}$ on the depurination rate is shown in Figures 1(a) and 2(a). The reaction rate with MS 2 RNA and hdpDNA decreased progressively at values above $\mathrm{pH} 4$, down to values which, in the case of hdpDNA, were nearly 20 -fold lower. Reaction rates with poly(A) were similar to those with the other substrates at the extremes of $\mathrm{pH}$, but there was a sharp increase between $\mathrm{pH} 5.5$ and 7.5 , with a maximum at 

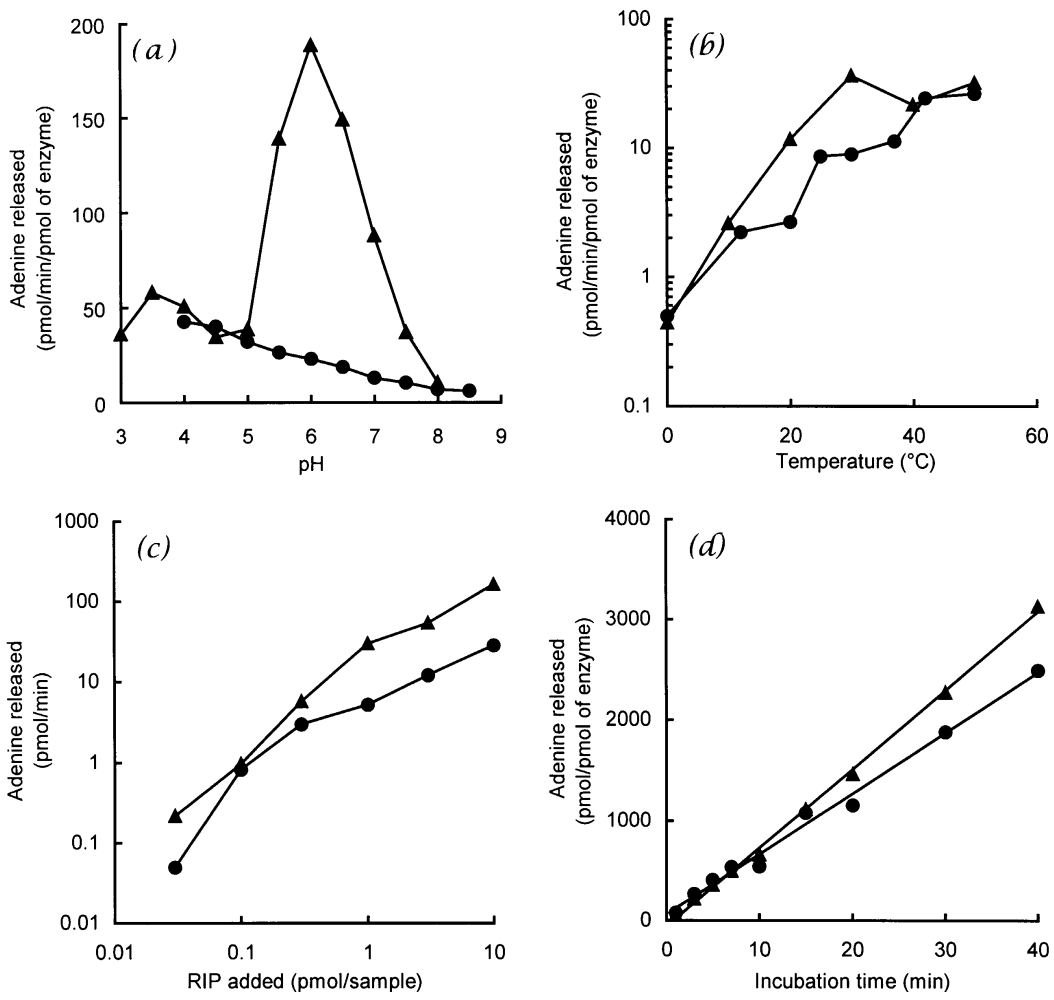

Figure 1 Polynucleotide:adenosine glycosidase activity of saporin-L1 towards MS 2 RNA and poly(A)

Reactions were carried out for 40 min at $25^{\circ} \mathrm{C}$ in a volume of $50 \mu \mathrm{l}$ in the presence of $0.3 \mathrm{pmol}$ of enzyme, $10 \mu \mathrm{g}$ of substrate [ $\mathrm{NH}_{4} \mathrm{Cl}$ and $10 \mathrm{mM}$ magnesium acetate, except for variations described for the respective experiments. (a) Effect of pH. Buffers used (20 mM) were: $\mathrm{pH} 8.5-6.5$, Tris/ $\mathrm{HCl}$; $\mathrm{pH}$ 6.0-3.5, sodium acetate buffer. Controls without enzyme at the extremes of $\mathrm{pH}$ and also at pH 6.0 in the case of poly(A) released $<0.1$ pmol of adenine/min. (b) Effect of temperature. Incubations were carried out at the indicated temperatures. The $\mathrm{pH}$ changed from 7.91 to 7.2 as the temperature varied from $0^{\circ} \mathrm{C}$ to $50^{\circ} \mathrm{C}$. Controls without enzyme at the extremes of temperature released $<0.1 \mathrm{pmol}$ of adenine/min. (c) Enzyme-concentration-response curves. Saporin-L1 was added at concentrations from 0.03 to 10 pmol/sample as indicated. Controls without enzyme released $<0.1$ pmol of adenine/min. (d) Time course. Optimal conditions deduced from experiments described in (a)-(c) were used. MS 2 RNA: 40 min at $30{ }^{\circ} \mathrm{C}$ in a volume of $50 \mu l$ in the presence of 0.3 pmol of enzyme, $10 \mu \mathrm{g}$ of substrate, $20 \mathrm{mM}$ sodium acetate buffer, $\mathrm{pH} 4.0,100 \mathrm{mM} \mathrm{NH}_{4} \mathrm{Cl}$ and $10 \mathrm{mM}$ magneium acetate. Poly $(\mathrm{A}): 40 \mathrm{~min}$ at $30{ }^{\circ} \mathrm{C}$ in a volume of $50 \mu$ in the presence of 0.3 pmol of enzyme, $10 \mu \mathrm{g}$ of substrate, $20 \mathrm{mM}$ sodium acetate buffer, $\mathrm{pH}$ 6.0, $100 \mathrm{mM} \mathrm{NH}_{4} \mathrm{Cl}$ and $10 \mathrm{mM}$ magnesium acetate. Controls were run with substrate but without enzyme for 40 min, and also with both substrate and enzyme but without incubation. Values obtained with the controls were $<3 \%$ of experimental values or within experimental error and thus were not considered important. Adenine released was measured by HPLC. Other experimental conditions are described in the Experimental section.

$\mathrm{pH}$ 6.0. The depurination rate with $\operatorname{poly}(\mathrm{A})$ at $\mathrm{pH} 6.0$ was 7 times higher than the rate with MS 2 RNA under the same experimental conditions. (ii) The ionic requirements for the depurination reaction catalysed by saporin-L1 are shown in Table 3. The ion species chosen for these determinations are those known to influence RIP activity towards ribosomes and to be important for several nucleic acid-modifying enzymes. With both poly(A) and hdpDNA the reaction proceeded at low ionic strength, in the absence of bivalent cations, of $\mathrm{K}^{+}$and $\mathrm{NH}_{4}^{+}$; no activity was observed in the presence of high ionic strength $(0.45 \mathrm{M} \mathrm{NaCl})$. Addition of $\mathrm{NH}_{4}^{+}$or $\mathrm{K}^{+}$accelerated the reaction rate with both substrates; the optimum has been determined with hdpDNA to be between 20 and $160 \mathrm{mM}$ (results not shown). Addition of $10 \mathrm{mM} \mathrm{Mg}^{2+}$ was always detrimental, except in the case of depurination of hdpDNA in the absence of $\mathrm{NH}_{4}^{+}$or $\mathrm{K}^{+}$; stimulation of activity was observed in this case at concentrations ranging from 0.31 to $15 \mathrm{mM}$ (results not shown). All the other bivalent cations tested decreased the reaction rate with poly(A) but had no effect on the reaction rate with hdpDNA. (iii) The optimal reaction temperature with poly(A) was $30^{\circ} \mathrm{C}$, whereas with MS 2 RNA or hdpDNA the reaction rate continued to increase up to $50{ }^{\circ} \mathrm{C}$, the highest temperature compatible with enzyme activity (Figure $1 \mathrm{~b}$ ).

\section{Kinetics of the reaction}

The following results were obtained. (i) The reaction rate was a function of enzyme concentration with four substrates: MS 2 and tobacco mosaic virus RNAs, poly(A) and hdpDNA (Figures $1 \mathrm{c}, 2 \mathrm{c}$ and 3 ). hdpDNA appeared to be the best substrate at very low concentrations of enzyme, whereas at high concentrations more adenine residues were released from poly(A). (ii) Timecourse experiments are shown in Figures 1(d) and 2(d). The reactions with MS 2 RNA and poly(A) as substrates proceeded linearly for at least $40 \mathrm{~min}$ (the incubation period usually employed), whereas with hdpDNA the reaction slowed down after $30 \mathrm{~min}$. When the reaction with poly(A) was run to exhaustion under the conditions detailed in the Experimental section, approx. $80 \%$ of the adenine residues were removed. (iii) The $K_{\mathrm{m}}$ and $k_{\text {cat }}$ values with poly(A) as substrate were calculated using two different sets of reaction conditions, one optimal for enzymic activity towards poly(A) as indicated by experiments reported in Figure 1, and a second that is optimal for poly(U)directed translation by mammalian ribosomes, a commonly used system for the evaluation of RIP activity. As shown in Table 4, the kinetic constants of the enzyme were highly dependent on the reaction conditions. 

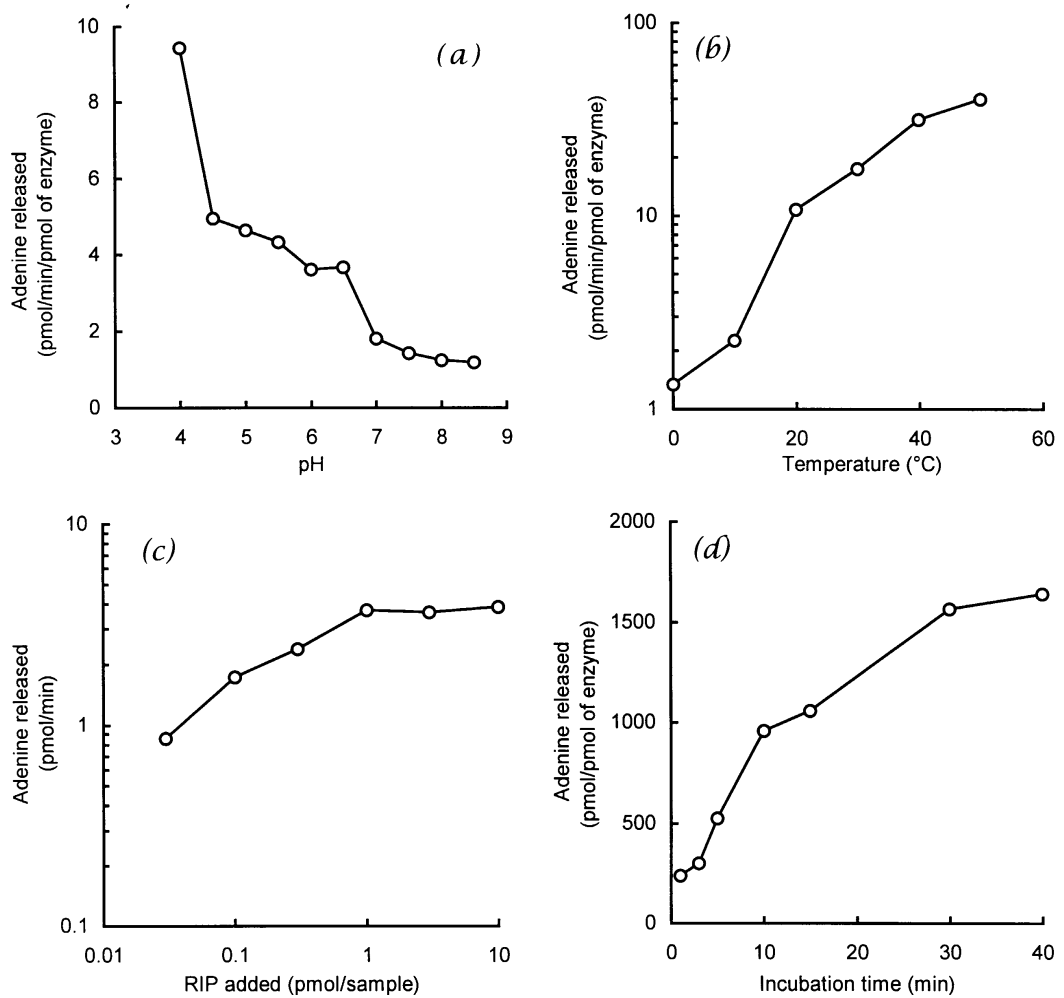

\section{Figure 2 Polynucleotide:adenosine glycosidase activity of saporin-L1 towards hpdDNA}

Reactions were carried out for $40 \mathrm{~min}$ at $30^{\circ} \mathrm{C}$ in a volume of $50 \mu \mathrm{l}$ in the presence of $0.17 \mathrm{pmol}$ of enzyme, $1 \mu \mathrm{g}$ of substrate, $50 \mathrm{mM}$ sodium acetate buffer, $\mathrm{pH} 4.0,160 \mathrm{mM} \mathrm{KCl}$ and 1.25 $\mathrm{mM}$ magnesium acetate, except for variations described for the respective experiments. (a) Effect of pH. Buffers used (50 mM) were: pH 8.5-6.5, Tris/HCl; pH 6.0-3.0, sodium acetate buffer. Controls without enzyme at the extremes of $\mathrm{pH}$ released $<0.1 \mathrm{pmol}$ of adenine/min. (b) Effect of temperature. Incubation was for 40 min at the indicated temperatures. The $\mathrm{pH}$ did not change significantly with temperature. Controls without enzyme incubated at $30{ }^{\circ} \mathrm{C}$ and $60{ }^{\circ} \mathrm{C}$ released less than $0.1 \mathrm{pmol}$ of adenine/min. (c) Enzyme-concentration-response curves. Reactions were carried out at the optimal temperature $\left(37^{\circ} \mathrm{C}\right)$ and $\mathrm{pH}(4.0)$, and saporin-L1 was added at concentrations from 0.03 to 10 pmol/sample as indicated. Controls without enzyme released $<0.1$ pmol of adenine/min. (d) Time course. Optimal conditions deduced from the experiments described in (a)-(c) were used: 40 min at $37^{\circ} \mathrm{C}$ in a final volume of $50 \mu$ in the presence of 0.17 pmol of enzyme, $10 \mu \mathrm{g}$ of substrate, $50 \mathrm{mM}$ sodium acetate buffer, $\mathrm{pH} 4.0,160 \mathrm{mM} \mathrm{KCl}$ and $1.25 \mathrm{mM}$ magnesium acetate. Controls with substrate but without enzyme incubated for 40 min released $<0.1$ pmol of adenine/min; controls with both substrate and enzyme but without incubation released $15.1 \mathrm{pmol}$ of adenine. Adenine released was measured by HPLC. Other experimental conditions are described in the Experimental section.

\section{Table 3 Effects of ions on the enzymic activity of saporin-L1}

Reaction conditions were optimal for each substrate (see the legends to Figures $1 \mathrm{~d}$ and $2 \mathrm{~d}$ ). Adenine released (pmol/min per mg of enzyme) was measured by HPLC as described in the Experimental section.

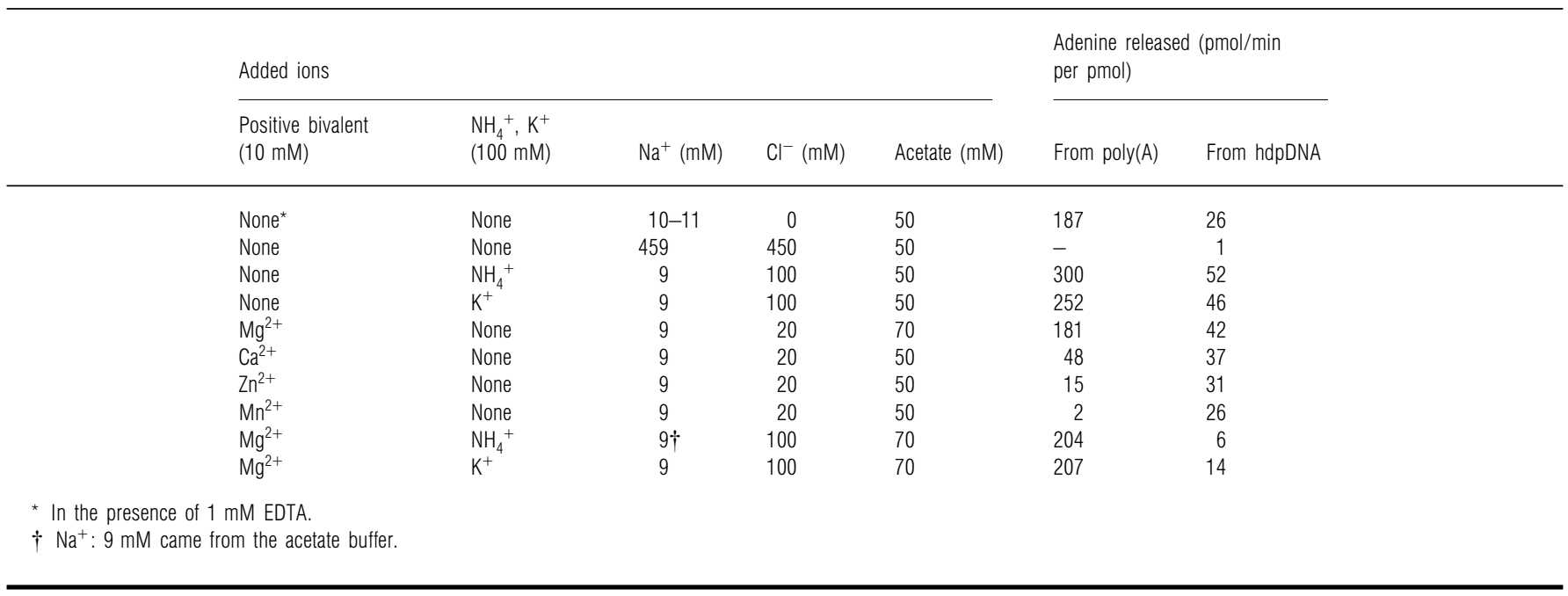




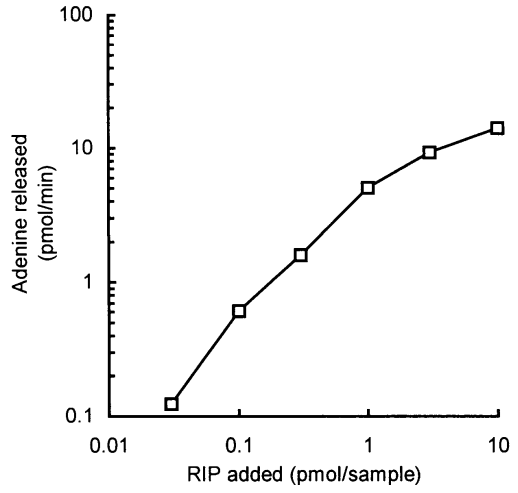

Figure 3 Polynucleotide:adenosine glycosidase activity of saporin-L1 towards tobacco mosaic virus genomic RNA

Reactions were in a volume of $50 \mu \mathrm{l}$ in the presence of $10 \mu \mathrm{g}$ of nucleic acid, $20 \mathrm{mM}$ Tris $/ \mathrm{HCl}$, $\mathrm{pH} 7.8,100 \mathrm{mM} \mathrm{NH}_{4} \mathrm{Cl}, 10 \mathrm{mM}$ magnesium acetate and saporin-L1 at the appropriate concentration, for $40 \mathrm{~min}$ at $25^{\circ} \mathrm{C}$. Controls were run with substrate but without enzyme for 40 min of incubation; values measured were within experimental error.

\section{Table 4 Kinetic constants for the action of saporin-L1 on poly(A)}

Reaction conditions, in a final volume of $50 \mu$, were either (i) $20 \mathrm{mM}$ sodium acetate buffer, $\mathrm{pH} 6.0,100 \mathrm{mM} \mathrm{NH}_{4} \mathrm{Cl}, 10 \mathrm{mM}$ magnesium acetate, 0.1 pmol of saporin-L1 and poly(A) at various concentrations, for $20 \mathrm{~min}$ at $30^{\circ} \mathrm{C}$ [optimal for poly(A)]; or (ii) $20 \mathrm{mM} \mathrm{Tris} / \mathrm{HCl}$, $\mathrm{pH} 7.8,100 \mathrm{mM} \mathrm{NH}_{4} \mathrm{Cl}, 10 \mathrm{mM}$ magnesium acetate, 1 pmol of saporin-L1 and poly(A) at various concentrations, for $20 \mathrm{~min}$ at $25^{\circ} \mathrm{C}$ [optimal for poly(U)-directed translation by mammalian ribosomes, a system commonly used to determine RIP activity]. Controls were run with substrate and enzyme without incubation; values (less than $<3 \%$ or within experimental error) were subtracted. Adenosine residues were the substrate considered for the calculation of kinetic constants. Adenine released was measured by HPLC. Other experimental conditions are described in the Experimental section.

\begin{tabular}{lrl}
\hline Conditions & $K_{\mathrm{m}}(\mu \mathrm{M})$ & $k_{\text {cat }}\left(\mathrm{min}^{-1}\right)$ \\
\hline $\mathrm{pH} 6.0,30^{\circ} \mathrm{C}$ & $65 \pm 14$ & $183 \pm 13$ \\
$\mathrm{pH} \mathrm{7.8,25}{ }^{\circ} \mathrm{C}$ & $639 \pm 32$ & $61 \pm 1$ \\
\hline
\end{tabular}

\section{DISCUSSION}

Since in preliminary experiments [13] the specificity of saporinL1 appeared to be much broader than that so far described for RIPs (the adenine residue identified by Endo and Tsurugi on the major rRNA [2]), several experiments were conducted to investigate specificity limits.

The possibility that depurination is caused by a host of minor contaminants seems unlikely, since: (i) the saporin-L1 protein is apparently highly purified (see the Experimental section), (ii) enzymic activity is still present at very low protein concentrations, (iii) the effect on protein synthesis and DNA depurination varies in the same direction in RIP-containing leaves ([14]; F. Stirpe, L. Barbieri, P. Gorini, P. Valbonesi, P. Bolognesi and L. Polito, unpublished work), (iv) all RIPs, including recombinant ones (L. Barbieri, P. Valbonesi, P. Gorini, A. Bolognesi and F. Stirpe, unpublished work), show activity towards hsDNA, and (v) to our knowledge, no other known enzyme has this activity.

Adenine and adenosine residues are common components of a variety of biological compounds. Several adenine-containing compounds, including cofactors, plant cytokinins and mono-

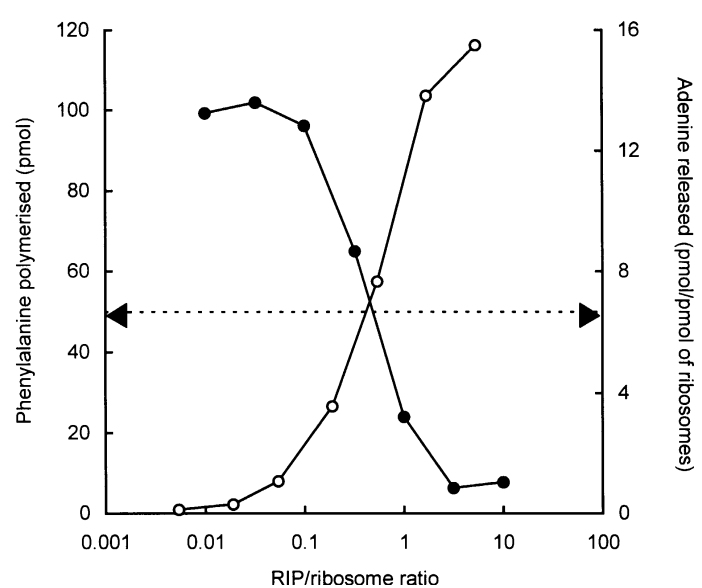

Figure 4 Effect of saporin-L1 on rat liver ribosomes: poly(U)-directed phenylalanine polymerization and adenine release

Phenylalanine polymerization; $\bigcirc$, adenine release. Experimental conditions are described in the text. For the determination of adenine release, only buffer and ions were added to the incubation mixture, and ribosomes were present at $20 \mathrm{pmol} / \mathrm{sample}$. Controls were run with ribosomes but without enzyme; values obtained were within experimental error. The broken line indicates the correspondence between $50 \%$ inhibition of translation and adenine release.

nucleotides, were not hydrolysed and did not compete with polynucleotide substrates. $\operatorname{Poly}(\mathrm{C})$, poly $(\mathrm{G})$ and poly $(\mathrm{U})$ were not substrates for the enzymic activity of saporin-L1, and no bases other than adenine were released from hsDNA. These results indicate that the specificity of the enzyme is restricted to adenine residues in polynucleotides.

Depurination of poly(A), RNA and DNA proceeds in the absence of any cofactor, although an influence of cofactors such as those characterized by Carnicelli et al. [4] cannot be excluded. The optimal $\mathrm{pH}$, ionic and temperature conditions are different for RNA, poly(A) and DNA as substrates. It remains to be shown whether this is due to an effect on the enzyme or to modifications of the different substrates. The polynucleotides used have different complex primary, secondary and tertiary structures which may undergo different modifications under varying experimental conditions.

DNA, RNA and poly(A) are all deadenylated by saporin-L1, indicating that both ribo- and deoxyribo-nucleotides are substrates for this enzyme and that a specific nucleotide sequence is not required. Rather, the lack of an effect on mononucleotides suggests a requirement for a chain of a certain length. The reaction with DNA slows down after $30 \mathrm{~min}$. This apparently is not due to inactivation of the enzyme, since the reactions with poly(A) and MS 2 RNA proceed linearly for at least $40 \mathrm{~min}$. An exhaustion of adenine residues can also be excluded, since only approx. $10 \%$ of those present in the reaction mixture were released. Thus it is possible that the enzyme does not have access to all adenosine residues present in the DNA, and that only those that were accessible to the enzyme were removed.

To our knowledge there are no enzymes with the activity described in this work. The nearest are probably DNA glycosylases (reviewed in [26]). These have a function similar to that of RIPs, in that they remove bases from the sugar-phosphate backbone, creating apurinic or apyrimidinic sites. Like saporinL1, they recognize a large substrate and specifically remove a single base of a given type. However, they differ from saporin-L1 
both functionally, since they remove only mismatched or anomalous bases, and structurally, in that no sequence identities were detected between DNA glycosylases and RIPs [27]. The only known sequence identities of RIPs are among ricin A chain and ribonuclease $\mathrm{H}$ and avian reverse transcriptases [28], and between gelonin and topoisomerase II from Drosophila melanogaster [12].

RIPs that release more than one adenine residue per ribosome show a lower inhibitory activity towards translation by rat liver ribosomes. The $\mathrm{IC}_{50}$ value of the effect of saporin-L1 on poly(U)directed polyphenylalanine synthesis is $11 \mathrm{nM}$ under our experimental conditions, roughly 10 times higher than that of other RIPs, e.g. PAP-S [1], that release only $\mathrm{A}^{4324}$ from ribosomes. When effects on translation and adenine release are compared, a $\mathrm{RIP} /$ ribosome molecular ratio giving $50 \%$ inhibition of translation corresponds to the release of more than 6.5 adenine molecules per ribosome (Figure 4). This contrasts with the effect of PAP-S, for which approx. 50\% inhibition corresponds to $50 \%$ deadenylation of ribosomes (results not shown). These observations indicate that several adenine residues are removed by saporin-L1 together with, or before, $\mathrm{A}^{4324}$, suggesting that this residue is neither the only one released nor the preferred one. This is consistent with the lower inhibitory activity of saporin-L1 on protein synthesis both in a cell-free system and in whole cells [7].

Saporins were initially identified from their action on mammalian ribosomes, and thus rRNA in mammalian ribosomes is a good substrate for all saporins, although it can hardly be considered to be a physiological substrate. In the case of saporinL1, poly(A) gave most product among all substrates tested (Table 1). However, if one considers that poly(A) contains more adenine residues, and that at low enzyme concentrations more adenine is released from hdpDNA, then the best substrate, together with ribosomes, appears to be DNA. If this phenomenon occurs in vivo, it would suggest that DNA and ribosomes are the best candidates for the natural substrates of these enzymes. Activity towards non-ribosomal RNA and poly(A) may be either accidental or represent the expression of a different biological role.

We are indebted to Dr. S. Hrelia for advice on kinetic analyses. This study was supported by grants from the Ministero dell'Università, from the C.N.R. (special projects 'Biotecnologie e Biostrumentazione' and 'ACRO'), from the Associazione Nazionale per la Ricerca sul Cancro, from the Regione Emilia-Romagna, and from the Pallotti's Legacy for Cancer Research.

\section{REFERENCES}

1 Barbieri, L., Battelli, M. G. and Stirpe, F. (1993) Biochim. Biophys. Acta 1154 , 237-282

2 Endo, Y. and Tsurugi, K. (1988) J. Biol. Chem. 263, 8735-8739

3 Girbés, T., Barbieri, L., Ferreras, M., Arias, F. J., Rojo, M. A., Iglesias, R., Alegre, C., Escarmis, C. and Stirpe, F. (1993) J. Bacteriol. 175, 6721-6724

4 Carnicelli, D., Brigotti, M., Montanaro, L. and Sperti, S. (1992) Biochem. Biophys. Res. Commun. 182, 579-582

5 Marchant, A. and Hartley, M. R. (1995) J. Mol. Biol. 254, 848-855

6 Barbieri, L., Ferreras, J. M., Barraco, A., Ricci, P. and Stirpe, F. (1992) Biochem. J. 286, $1-4$

7 Ferreras, J. M., Barbieri, L., Girbés, T., Battelli, M. G., Rojo, M. A., Arias, F. J. Rocher, M. A., Soriano, F., Méndez, E. and Stirpe, F. (1993) Biochim. Biophys. Acta 1216, 31-42

8 Teltow, G. J., Irvin, J. D. and Aron, G. M. (1983) Antimicrob. Agents Chemother. 23 390-396

9 Stirpe, F., Derenzini, M., Barbieri, L., Farabegoli, F., Brown, A. N. F., Knowles, P. P. and Thorpe, P. E. (1987) Virchows Arch. B 53, 259-271

10 McGrath, M. S., Hwang, K. M., Caldwell, S. E., Gaston, I., Luk, K.-C., Wu, P., Ng V. L., Crowe, S., Daniels, J., Marsh, J., Deinhart, T., Lekas, P. V., Vennari, J. C., Yeung, H.-W. and Lifson, J. D. (1989) Proc. Natl. Acad. Sci. U.S.A. 86, 2844-2848

11 McGrath, M. S., Santulli, S. and Gaston, I. (1990) AIDS Res. Hum. Retroviruses 6, 1039-1043

12 Lee-Huang, S., Huang, P. L., Kung, H.-F., Li, B.-Q., Huang, P. L., Huang, P., Huang, H. I. and Chen, H.-C. (1991) Proc. Natl. Acad. Sci. U.S.A. 88, 6570-6574

13 Barbieri, L., Gorini, P., Valbonesi, P., Castiglioni, P. and Stirpe, F. (1994) Nature (London) 372, 624

14 Stirpe, F., Barbieri, L., Gorini, P., Valbonesi, P. Bolognesi, A. and Polito, L. (1996) FEBS Lett. 382, 309-312

15 Allen, E. H. and Schweet, R. S. (1962) J. Biol. Chem. 237, 760-767

16 Aviv, H. and Leder, P. (1972) Proc. Natl. Acad. Sci. U.S.A. 69, 1408-1412

17 Chirgwin, J. J., Przbyla, A. E., MacDonald, R. J. and Rutter, W. J. (1979) Biochemistry 18, 5294-5299

18 Bøyum, A. (1968) Scand. J. Clin. Invest. 21 (Suppl. 97), 77-89

19 Maniatis, T., Fritsch, E. F. and Sambrook, J. (1982) Molecular Cloning: A Laboratory Manual, Cold Spring Harbor Laboratory Press, Cold Spring Harbor

20 McCann, W. P., Hall, L. M. and Nonidez, W. K. (1983) Anal. Chem. 55, 1455-1456

21 Zamboni, M., Brigotti, M., Rambelli, F., Montanaro, L. and Sperti, S. (1989) Biochem. J. 259, 639-643

22 McCann, W. P., Hall, L. M., Siler, W., Barton, N. and Whitley, R. J. (1985) Antimicrob. Agents Chemother. 28, 265-273

23 Arias, F. J., Rojo, M. A., Ferreres, J. M., Iglesias, R., Muñoz, R., Rocher, A., Méndez, E., Barbieri, L. and Girbés, T. (1992) Planta 186, 532-540

24 Montanaro, L., Sperti, S., Zamboni, M., Denaro, M., Testoni, G., Gasperi-Campani, A. and Stirpe, F. (1978) Biochem. J. 176, 371-379

25 Staehelin, T. and Falvey, A. K. (1971) Methods Enzymol. 20, 433-446

26 Lindhal, T. (1982) Annu. Rev. Biochem. 51, 61-87

27 Olsen, L. C., Aasland, R., Wittwer, C. U., Krokan, H. E. and Helland, D. E. (1989) EMBO J. 8, 3121-3125

28 Ready, M. P., Katzin, B. J. and Robertus, J. D. (1988) Proteins 3, 53-59

Received 27 February 1996/19 June 1996; accepted 2 July 1996 